Georgia State University

ScholarWorks @ Georgia State University

Middle and Secondary Education Faculty

Publications

Department of Middle and Secondary Education

2-9-2017

\title{
More than a feeling: Tracing the progressive era origins of historical empathy in the social studies curriculum, 1890-1940s
}

Katherine A. Perrotta

Georgia Perimeter College

Chara H. Bohan

Georgia State University

Follow this and additional works at: https://scholarworks.gsu.edu/mse_facpub

Part of the Curriculum and Instruction Commons, and the Junior High, Intermediate, Middle School Education and Teaching Commons

\section{Recommended Citation}

Perrotta, Katherine A. and Bohan, Chara H., "More than a feeling: Tracing the progressive era origins of historical empathy in the social studies curriculum, 1890-1940s" (2017). Middle and Secondary Education Faculty Publications. 72.

https://scholarworks.gsu.edu/mse_facpub/72

This Article is brought to you for free and open access by the Department of Middle and Secondary Education at ScholarWorks@ Georgia State University. It has been accepted for inclusion in Middle and Secondary Education Faculty Publications by an authorized administrator of ScholarWorks @ Georgia State University. For more information, please contact scholarworks@gsu.edu. 


\title{
More than a feeling: Tracing the progressive era origins of historical empathy in the social studies curriculum, 1890-1940s
}

\author{
Katherine Assante Perrotta and, Chara Haeussler Bohan \\ Georgia State University, Department of Middle and Secondary Education, P.O. Box 3978, Atlanta, GA \\ 30303-3978 USA
}

\section{Introduction}

Understanding historical empathy is a bourgeoning subfield of social studies education research. Students demonstrate historical empathy by analyzing sources 1 ) to determine historical context, 2) identify perspectives of historical figures, and 3) make affective connections to historical content. Much of the existing scholarship focuses on teaching methods that can foster historical empathy among elementary and secondary social studies students. Studies spanning 20 years highlight that students are capable of engaging in historical empathy through debate (Jensen, 2008), film analysis (Metzger, 2012), Socratic questioning sessions (Kohlmeier, 2005), and source analysis and narrative writing (Author, 2016; Barton, 1996; Brooks, 2011; Colby, 2008; Endacott, 2013; Foster, 1999). Although student demonstration of these skills is important, historical empathy is not an explicitly stated curricular goal in most state and national social studies standards.

As scholarship on historical empathy grows among social studies researchers and practitioners, so does the need to examine its theoretical and pedagogical roots as a curricular goal in social studies.

Therefore, the purpose of this research is to examine primary sources from educational leaders and organizations during the progressive era in American public school education in order to trace the origins of historical empathy as an implicit goal in the social studies curriculum. Our guiding research question is "How does the work of Progressive Era organizations and educational leaders impact how Americans viewed historical empathy?" We purposefully selected documents from Progressive Era organizations and certain leaders whose work formed a strong foundation of social studies education history. We conclude with an examination of the importance of historical empathy today in order to demonstrate the importance of historical empathy as a curricular aim of social studies education.

\section{Historical empathy defined}

Historical empathy involves intellectual and affective dimensions of historical thinking that "develop from the active engagement in thinking about particular people, events, and situations in their context" (Davis, 2001, p. 3). According to Yilmaz (2007), historical empathy "is the skill to re-enact the thought of a historical agent in one's mind or the ability to view the world as it was seen by the people in the past without imposing today's values on the past" (p. 331). Historical empathy is not the practice of simply pretending to walk in someone else's shoes, but the process of 1) evaluating historical context and significance, 2) identifying perspectives, and 3) making affective connections (Brooks, 2011).

*Correspondence to: 5560 Oxborough Way, Alpharetta, GA 30005 USA.

E-mail addresses: Kassanteperrotta@yahoo.com (K.A. Perrotta), Cbohan@gsu.edu (C.H. Bohan).

http://dx.doi.org/10.1016/j.jssr.2017.01.002 
Scholars use several terms to define historical empathy. The terms "perspective recognition" (Barton \& Levstik, 2004) and "perspective taking" (Davis, 2001; Duhlberg, 2002) have been used interchangeably to mean historical empathy. Endacott (2014) notes that perspective recognition means identifying with a particular person's point of view, versus perspective taking, which refers to the dialogue students engage in when considering their perspectives, as well as others' point of views. Consequently, demonstration of historical empathy through historical study involves both perspective recognition and perspective taking.

Furthermore, debate persists on whether historical empathy is only achievable in social studies. One concern is that the term historical empathy is only "particular to history" (Lee \& Shemilt, 2011, p. 40). Blake (1998) argues for the use of the phrase "empathy in history" due to the misconception that empathy is not relevant or achievable in other academic disciplines (p. 26). Brooks (2009) notes that Blake's call for the use of the term "empathy in history" is valid point because it 1"conceptualizes empathy as involving a range of skills, insights, and feelings, which are commonly applied in any field of study" (p. 217). In short, a major issue with defining the term historical empathy is the connotation that empathy is something only achievable or relatable to history and/or social studies content.

Despite the discrepancies about the exact theoretical meaning of historical empathy, agreement exists with regard to how scholars describe its instructional elements. Endacott and Brooks (2013) provide an updated theoretical conceptualization for teaching historical empathy through narrative writing. Their theoretical conceptualization outlines "three interrelated and interdependent endeavors" that combine the three cognitive acts of 1) historical contextualization, 2) perspective talking, and 3) affective connection (p. 43). Additionally, this framework emphasizes the importance of using multiple texts to engage students in the intellectual and emotive acts of historical empathy. For instance, Marcus, Metzger, Paxton, and Stoddard (2010) contend that teachers can promote historical empathy by engaging in film-based instruction for students to practice recognizing and explaining the viewpoints of people and groups from the past. For the purposes of this research, the researchers use Endacott and Brooks' (2013) definition as their criterion for tracing the origins of historical empathy back to progressive era curricular documents. This definition not only represents a consensus of the scholarly definition of historical empathy as a pedagogical tool, but is most effectively used to analyze for evidence of the existence of historical empathy as an unstated curricular goal in social studies education.

\section{The Early Progressive Era, 1880-1900s}

The progressive era was a time when grassroots and governmental reforms were enacted to address the socio-economic and political ills of the Gilded Age. Among these ills included unfettered laissez-faire capitalism, corporate monopolies, industrialization, urbanization, child labor, and racial discrimination. For example, Riis (1901) indicated in his quintessential, How the Other Half Lives, "what are you going to do about it? is the question of to-day" with regard to the disparities in American society at the end of the 19th century (p. 2). In response to this question, reformers from various walks of life became involved in social causes. These causes, which included legislative action addressing labor, housing, consumer protections, public health, and education highlighted growing socio-economic and political inequalities in the United States, particularly in American schools.

During the Progressive Era, the purpose of schooling "became the core upon which Americans relied to assure the continuity and evolution of their government, their economy, and their social values" 
(Graham, 2005, p. 3). Traditionally, the aim of history in American public schools focused on promoting virtues and morals necessary to cultivate citizenship in the early republic through teacher-centered instruction of the classics (Author, 2005; Evans, 2004; Reese, 2007). After the Civil War, the influx of immigrants and abolition of slavery spurred a rapid urbanization that changed the stated purpose of American public schooling, particularly in history and social studies education. As a result, progressive educational reformers called for a holistic curriculum that focused social studies content that prepared children for work, life, and citizenship in the 20th century.

Additionally, the history and education fields became "professionalized" as the acquisition of higher education degrees became "license" to practice history at colleges and universities as a means to prepare students for life and "intellectual enjoyment" (Committee of Ten, p. 28; Novick, 1988, pp. 63, 64). Several professional organizations formed during this time period that worked towards establishing the modern secondary education curriculum. We found evidence from documents produced by some of these organizations, particularly the National Education Association (NEA) and the American Historical Association (AHA), that demonstrate the emergence of historical empathy as an implicit curricular goal in history and social studies instruction. The NEA and AHA established committees such as the Report of the Committee on Secondary School Studies (hereafter referred to the NEA Committee of Ten) and The Study of History: Report to the American Historical Association by the Committee of Seven (hereafter referred to the AHA Committee of Seven) to evaluate the purpose and components of secondary education in American schools. The efforts of these committees included defining history education, identifying requirements of history education in K-12 schools, determining curricular content and goals, and advocating for more pedagogical teaching methods. Although never stated directly, evidence in these documents alludes to the existence of historical empathy as a curricular goal in history education.

\section{The Committee of Ten}

The NEA Committee of Ten convened in 1892 to propose recommendations with regard to the high school curriculum to determine which subjects should be taught to better prepare students for college and life. MacKenzie (1894) noted that a major objective for these reforms was to ensure that "a national system of education...aims at certain common results and uses common means, involving compromise and yielding of individual judgments, for the common good" (p. 148). Several discipline-specific committees formed to recommend curricular reforms. The Madison Conference, which was charged with examining curricular recommendations for history and civics education, recommended implementing the "proper apparatus for teaching history, such as maps, reference-libraries, historical pictures, and photographs" to make history instruction "interesting and suggestive," as well as supported by interdisciplinary study (Saxe, 1991, p. 295).

The Madison Conference proposed that history be incorporated into multi-disciplinary instruction to support historical comprehension as well as scientific, mathematical, and humanities studies. According to Author (2003) and Reese (2001), the Committees intimated that history be "laboratories of democracy" to foster citizenship, assimilation, and "social stability and moral uplift" through source analysis of documents and objects instead of teacher-centered lectures. Eliot (1898), Harvard University President and chairman of the Committee of Ten supported these assertions, stating that a major purpose of education "and all the experience of life...all tend strongly to magnify innate diversities...an inflexible programme is fighting not only against nature, but against the interests of democratic society" 
(p. 420). The Madison Conference (1892) recommended three methods of history instruction that implicitly identifies historical empathy as a curricular goal in this report. These methods include:

21. Resolved, That pupils should be required to read or learn one other account besides that of text-book on each lesson [Report, 27-29.].

22. Resolved, That the method of study by topics be strongly recommended, as tending to stimulate pupils and to encourage independence of judgment [Report, 33.]

23. Resolved...by reading historical sketches, biographies and novels, outside of class work [Report, 30-31.] (p. 164).

Since historical empathy involves source analysis of multiple documents to determine historical context and authors' perspectives to make affective connections to content, we believe this evidence supports the unstated concept of historical empathy as a curricular goal in history.

The Committee of Seven

The AHA Committee of Seven convened in 1896 to address the multiple points the Committee of Ten Madison Conference raised with regard to the secondary history education curriculum. In its 1898 report, the Committee of Seven added to the Committee of Ten's recommendations for an interdisciplinary approach to history education with multiple texts and sources, stating:

We do not ask that pupils should be required to do so-called 'laboratory work'-we abjure the phrase-and create histories out of absolutely unhewn and unframed material; we simply say that if a pupil is taught to get ideas and facts from various books, and to put those facts together into a new form, his ability to make use of knowledge is increased and strengthened (AHA, 1898).

Although this excerpt suggests that the Committee of Seven supported a more traditional approach to history education, this report hinted at notions historical empathy with regard to student analysis of texts for historical context and perspectives of authors. For instance, in the section of the report on "The Value of History," the Committee of Seven (1898) states:

History cultivates the judgment by leading the pupil to see the relation between cause and effect, as cause and effect appear in human affairs...But history has to do with the becoming of past events, not simply with what was, but with what came to be, and in studying the simplest forms of historical narrative even the average pupil comes to see that one thing leads to another; he begins quite unconsciously to see that events do not simply succeed each other in time, but that one grows out of another, or rather out of a combination of many others. Thus, before the end of the secondary course the welltrained pupil has acquired some power in seeing relationships and detecting analogies.

This excerpt highlights the report's implicit curricular goal of historical empathy with its emphasis on student identification of the relationship between cause and effect from narratives in particular historical contexts. 
The report alludes to the implicit existence of historical empathy as a curricular goal by mentioning that students should gain an appreciation and sympathy when analyzing historical texts. In this same section of the report, the AHA (1898) notes:

We desire to emphasize the thought that appreciation and sympathy for the present is best secured by a study of the past; and while we believe that it is the imperative duty of every high school and academy to teach boys and girls the elementary knowledge of the political machinery which they will be called upon to manage as citizens of a free state, we insist also that they should have the broader knowledge, the more intelligent spirit, that comes from a study of other men and of other times. They should be led to see that society is in movement, that what one sees about him is not the eternal but the transient....

Although the use of term sympathy in this report can be interpreted as the Committee of Seven's allusion to historical empathy, conflating it with sympathy is problematic. Some scholars caution that misconstruing historical empathy with sympathy could imply condoning the actions of the "wrong" people in history (Lee \& Ashby, 2001, p. 22). Although Noddings (2002) and Seixias and Peck (2004) contend it is important for students to investigate the motives and actions of those who commit heinous acts as consideration of various perspectives in history instruction, achieving sympathy for others is not an objective for demonstrating historical empathy. Nevertheless, the report's reference to the role of student identification of cause and effect, relationship between historical context in texts, and sympathy when teaching with historical texts suggests that the emerging concept of historical empathy as a curricular goal existed.

\section{Application of committees' recommendations for history instruction}

Several progressive educators and scholars, some of whom served on the Committees, continued to implement progressive pedagogies that focused on the development of the child and education for "the common good" (MacKenzie, 1894, p. 148). For instance, Lucy Maynard Salmon, who was a History Professor at Vassar College and the singular female who served on the Committee of Seven, was a major proponent of teaching history with the "source method" by analyzing everyday items, such as newspapers. Salmon's works provides evidence of the developing support for historical empathy in progressive history, and later, social studies education (Author, 1999, p. 48). Fling (1924), prominent progressive era educator and scholar, wrote that Salmon's book The Newspaper and the Historian had "not only of great value to the historian, but also to the economist, political scientist and sociologist. She has presented...her matter in such attractive form that even the man on the street might read the book with pleasure and profit" (p. 711). Fling's review highlights the implied existence of historical empathy as a curricular goal in Salmon's work with her emphasis on consideration of historical context, perspectives, and affective connections to content (Colby, 2007).

Despite the persistence of debates about the history curriculum, some suggestive evidence of the implicit curricular goal historical empathy can be found in later reports by the AHA Committee of Eight and Committee of Five. In 1905, the Committee of Eight issued its recommendations for history instruction in elementary school. Building upon the advice of the Committee of Ten Madison Conference and Committee of Seven, James Alton James (1905) contends: 
Our fundamental proposition is, that history teaching in the elementary schools should be focused around American history. By this we do not mean to imply that American history has to do with events, alone, which have occurred in America. The object is to explain the civilization, the institutions, and the traditions of the America of to-day. America cannot be understood without taking into account the history of its various groups before they crossed the Atlantic (pp. 3-4).

By emphasizing the importance of students making connections to the multiple experiences of peoples that constitute the diversity of American history. According to Author (2009), the recommendations of this committee served as a "blue- print" for teaching United States history from first to eighth grades.

In 1911, the AHA Committee of Five issued its report to re-examine the impact of the Committee of Ten and Seven's recommendations on history instruction in elementary and secondary schools. The committee found that while schools were taking history more seriously with regard to rigor of instruction and curriculum development, the Committee recommended that more time should be devoted to modern history instruction. The researchers found little evidence in this report that supported the unstated curricular goals of historical empathy. However, the efforts of the Committee of Eight and Five brought standardization and uniformity to history instruction in elementary and secondary schools with regard to the chronological sequencing of American history content, inclusion of world history in the curriculum, and affirming history's position as a major subject area that prepared students for life and citizenship (Author, 2001; Evans, 2004, p. 69).

\section{Committee of social studies}

Major strides in implementing progressive reforms to social studies education came to fruition with the 1913 Commission on the Reorganization of Secondary Education (CRSE). The Report of the Committee on Social Studies (CSS) was issued in 1916, which emphasized that social studies education was "whose subject matter relates directly to the organization and development of human society, and to man as part of social groups" (CSS, 1916, p. 9). The authors of the report, including CSS chairman and Hampton Institute educator Thomas Jesse Jones, proposed that social studies be a vehicle to promote civics and citizenship through the study of current issues, world and United States historical content, and problems of American democracy in order to "encourage and direct the application...[to] the student's need in all the future work of the school" (Jones, 1906, p. 5-6; Vinovskis, 1999, p. 19; Vinson \& Ross, 2001). By highlighting the instructional goals for students to make connections to contemporary issues through the study of historical narratives, the CSS implicitly advocated for curricular reforms that fostered historical empathy among secondary students.

In the "Introduction," the CSS (1916) stated, "social studies should cultivate a sense of membership in the 'world community,' which with all the sympathies and sense of justice that this involves as among different divisions of human society" (p. 9). Moreover, Part III of the CSS 1916 Report also alludes to historical empathy with a focus on sympathy. With regard to the aims of history, the Committees' General Statement of Principles of Organization (1916) states:

One of the conscious purposes of instruction in the history of nations other than our own should be the cultivation of a sympathetic understanding of such nations and their peoples, of an intelligent appreciation of their contributions to civilization, and of a just attitude toward them (p. 39). 
Similar to the reference to the AHA Committee of Seven, the CSS reference to sympathy raises problems with regard to possibly condoning the actions of evil people in history. Although the role of sympathy in social studies as a vehicle to understand perspectives, historical context, and perspectives of others is evident in both the CSS and Committee of Seven, none of these early reports specifically state that historical empathy should be a curricular goal. The fact that the term sympathy exists in these documents suggests that despite the tug-of-war between traditional history and progressive social studies curriculum evident in these committee reports, historical empathy established stronger roots in the progressive era when reformers advocated for the consideration of various perspectives in order to determine historical significance.

Further evidence from the CSS 1916 Report that points to the implicit curricular goal of historical empathy exists in its suggestion for a course pertaining to problems of American democracy. In particular, the Report highlights the socioeconomic and political impact of immigration on the United States as a reason to foster the "social mind" of students by:

...Giv[ing] experience and practice in the observation of social phenomena as he encounters them; that lie should be brought to understand that every social problem is many-sided and complex; and that he should acquire the habit of forming social judgments only on the basis of dispassionate consideration of all the facts available ( $p$. 55-56).

This emphasis on students experiencing and observing the complexities of social problems demonstrate to the researchers that historical empathy was an unstated curricular goal in this report with regard to connecting perspective recognition, identification and examination of historical context to progressive era social studies instruction.

Following up on the CSS in 1916, the NEA published The Cardinal Principles of Secondary Education two years later. The 1918 Report emphasizes that as the nation's school populations change, secondary curricula, educational theory, and pedagogy must foster democratic principles in order ensure that "each member may develop his personality primarily through activities designed for the well-being of his fellow members and of society as a whole" (p. 9). Although the Report focuses mostly on ethics, physical education and health, vocational studies, civics, and the organization of schools, the report references historical empathy with regard to the aim of social studies and history in secondary education. Part IV of the

Report (1918) states:

While all subjects should contribute to good citizenship, the social studies: geography, history, civics, and economics should have this as their dominant aim... History should so treat the growth of institutions that their present value may be appreciated. Geography should show the interdependence of men while it shows their common dependence on nature. Civics should concern itself with constitutional questions and remote governmental functions-and should direct attention to social agencies close at hand and to the informal activities of daily life that regard and seek the common good (p. 14). 
The Report demonstrates the implicit curricular goals of historical empathy in several ways. First, its contention that history instruction should be comprised of student analysis of the value of social institutions suggests that for historical empathy to develop, the curricular goals of perspective recognition and examination of historical context must take place. Second, the Report's support of teaching other social studies disciplines by emphasizing the interdependence of people to other groups, the natural environment, and social institutions suggests that historical empathy was conceived as an unstated goal for secondary instruction that promoted citizenship and personal development.

\section{Birth of the National Council for the Social Studies}

Momentum for progressive social studies in American public schools continued to grow after the publication of the AHA and NEA reports from 1905 to 1918. The National Council for the Social Studies (NCSS) was founded in 1921 by Teacher's College faculty, including Earle Rugg, and the AHA to "coordinate work in the field with the NEA" (Evans, 2004, p. 37). The Historical Outlook (1921) noted that NCSS was established in order to "obtain the maximum results in education for citizenship through social studies" (p. 144). By the mid-1920s, the purpose of NCSS was to bring "together people with a variety of conceptions of what 'social studies' means," particularly among schoolteachers, professors of teacher education, and historians (Thornton, 1996, p. 3-4). Although the AHA maintained traditional notions of history instruction with the "uncritical transmission of historical information," founding members maintained that the purpose of "social studies [was] the product of interests in social progress involving broader social and intellectual concerns" (Nelson, 2001, p. 19).

Similar to the reports of the early Progressive Era, historical empathy was not recognized as a stated curricular goal in history and social studies instruction by NCSS. However, with regard to greater coordination of teaching history and social studies as prescribed by the NEA and AHA as "a sort of experimental enterprise" in schools (The Historical Outlook, 1921, p. 322), Johnson (1922) notes:

Development, continuity, unity-these three words sum up the unique contribution of history to human knowledge of humanity through the ages and furnish a clue to the nature of what we call human progress. If they are true words, if we are in the midst of a continuous process of becoming, then history that traces development is an indispensable instrument for understanding our stage in the process, our changing customs, our changing institutions and ideals, our changing selves and other changing human beings now living and working in the world (p. 327).

Johnson's essay highlights the implicit curricular goals of historical empathy by contending that history and social studies education must involve student analysis of the contexts in which people develop perspectives on issues in order to understand rapid socio-economic and political changes taking place. Overall, the establishment of NCSS further supported historical empathy as an implicit curricular goal with its emphasis on preparing students to live and work with diverse people and groups through examination of historical perspectives and contexts.

\section{The Later Progressive Era, 1921-1940s}

The decades following World War I witnessed great changes in American society, as well as progressive reforms to social studies education. These sweeping changes included the Harlem Renaissance, "return to normalcy" with regard to U.S. foreign affairs, female suffrage, prohibition, and the Great Depression. 
Although much of history education in the post-war decades still emphasized patriotism, greater attention was brought to progressive pedagogy that promoted historical empathy through analysis of sources and contemporary issues in elementary and secondary schools. Consequently, the growing support of social studies instruction in primary and secondary schools further evidences the origins of historical empathy as an implicit curricular goal during the later progressive era.

Harold Rugg and "Problems of Democracy"

After World War I, progressive era educators and scholars continued to champion for social studies education that focused on developing students' historical content knowledge that could be applied to understanding contemporary socio- economic and political issues facing the United States. Teachers College professor Harold Rugg, brother of NCSS founder Earle Rugg, was a prominent advocate of progressive social studies education that focused on the needs of individual students and society (Nelson, 1975, p. 60, 62). Building upon the works of the CRSE, CSS, and NCSS, Rugg wrote pamphlets that eventually constituted the textbooks for his "Problems of Democracy" curriculum. This curriculum called for "an activist, democratically generated reconstruction of society" (Boyle-Baise \& Goodman, 2009, p. 32) by examining contemporary issues in history and geography courses (Mraz, 2004).

Although Rugg's curriculum has been examined carefully, it has never been analyzed for the purpose of determining whether it promoted the implied skills of historical empathy. We, however, found examples in which Rugg promoted historical empathy in his curriculum. For instance, Rugg (1929) identified the role of oil in technological advancement and corporate waste in An Introduction to American Civilization: A Study on Economic Life in the United States. He noted, "the story of oil production since 1900 reveals even more distressing examples of waste than that of the production of coal" (Rugg, 1929, p. 135). The book has accompanying illustrations with political cartoons and photographs of oil rigs. Rugg was critical of corporate business practices on the environment and laborers, yet he advised teachers to allow students to critically analyze the book's content. He stated in the Teacher's Guide for an Introduction to American Civilization:

There will be a tendency for the pupil to conclude that industrial civilization has been a benefit to everyone in the United States. It is such forgone conclusions that the teacher should caution the pupil against making. This book may be thought to portray a glowing picture of our American industrial civilization. The pupil should come to realize, however, that as yet the facts are not all in" (Rugg \& Mendenhall, 1929, p. 101).

In this example, Rugg urges students and teachers to consider different viewpoints on issues in order to make conclusions not only based on presented data, but to also scrutinize information that was not included or available in the texts. This excerpt suggests the unstated existence of historical empathy in Rugg's curriculum as students are encouraged to consider different perspectives in order to examine the historical context of 19th and 20th century American industrialization.

Rugg's legacy is controversial. Davis (2012) notes that Rugg's curriculum had weaknesses, specifically due to the lack of evidence that his textbooks were used in poor and underserved schools with large black and immigrant populations. Hence, the books may have only served "students who were intellectually bright and from upper middle class backgrounds" (p. 8). Moreover, Evans (2004) 
acknowledges that Rugg's "fatal mistake was that he and his research team sometimes failed to include competing or dissenting ideas" when presenting historical and contemporary problems (p. 41).

Organizations such as the American Legion and Daughters of the Revolution (DAR) supported banning his books from public schools on the grounds the curriculum was subversive and "un-American" (Dorn, 2008, p. 465).

Moreover, criticisms of Rugg's curriculum reverberated among prominent progressive scholars and colleagues at Teachers College, among them John Dewey. Dewey (1938) stated "now we have the problem of discovering the connection which actually exists within experience between the achievements of the past and issues of the present" (p. 397, 399).

Similar to Davis' (2012) concerns about the social studies curriculum, Dewey contended that asking elementary and secondary students to solve complex social problems by connecting affective responses to the intellectual skills of identifying perspectives and historical content was "a frivolous undertaking and a mockery of decision-making" (p. 7). Although Rugg's textbooks were not universally adopted in social studies and history classrooms, his curricular focus on engaging students in critical analysis of contemporary and historical issues hints to his support for the concept of historical empathy.

\section{Rachel Davis DuBois and the intercultural education movement}

Further evidence of the implementation of historical empathy as an implied curricular goal during the later progressive era can be seen in the works of Rachel Davis DuBois. She initiated the "intercultural education movement" (ICEM) with the purpose of implementing the "contributions approach" to promote tolerance and awareness of different cultural groups in the social studies curriculum (Bradley, 2007, p. 72; Lal, 2004, p. 20). Progressive era works on race and immigration influenced DuBois' teaching and research career. She fashioned her ICEM program around Carter G. Woodson's Negro History Week curriculum and used Rugg's textbooks, such as Culture and Education in America, as a teacher at Woodbury High School during the 1920s (Author, 2007, p. 105; DuBois \& Okorodudu, 1984, p. 71). Her "Woodbury Plan," named after the high school where she taught in New Jersey, featured assemblies, speakers, musicians, and artists of particular cultures to promote intercultural and multicultural education (Author, 2007; Davis, 1999). DuBois (1942) stated that the "festival method" for promoting ICEM initiatives "is capable of diverse application...used in churches, Americanization classes, parentteacher associations and schools, community centers, and even in homes...It demands only the willingness of a leader or leaders and a group" (p. 17). DuBois' ICEM was a pioneering initiative that promoted historical empathy by 2engaging students with a "contributions approach" to learning about different peoples during the later years of the progressive era in American education (Pitkin, 1948).

Furthermore, DuBois helped expand concepts of historical empathy with the establishment of the Service Bureau of Intercultural Education. The purpose of the Bureau was to provide teachers and schools resources to teach and promote ICEM initiatives. The Bureau also produced and hosted the radio show "Americans - All, Immigrants-All" with the intention of bringing "intercultural understanding to a wide American audience" (DuBois \& Okorodudu, 1984, pp. 86-87). The goals of the radio program, as well as the Bureau's ICEM resources, aimed at rejecting "the biases and distortions in textbooks" that were prevalent in mainstream school curricula and American society (Davis, 1999, p. 174; Savage, 1999). These biases are attributed to the fearful sentiments during the First Red Scare, the resurgence of the Ku Klux Klan, and the socio-economic 3competition between native-born Americans and immigrants that led to the rise of nativist sentiments that was often reflected in school curricula. For 
instance, David Muzzey's textbook An American History often "espoused ethnocentric and racist views" about Native Americans and African Americans who were viewed as "an earlier form of development" (Fallace, 2012, p. 49).

Over the span of four decades, DuBois published several books aimed at implicitly promoting historical empathy by advocating for dialogue and cultural understanding between diverse groups. Some of these works include National Unity Through Intercultural Education (1942), Get Together Americans: Friendly Approaches to Racial and Cultural Conflicts Through the Neighborhood-home Festival (1943), Know Your Neighbors: A Handbook for Group Conversation Leaders (1955), and The Art of Group Conversation: A Breakthrough in Social Communication (1963). She alluded to the concept of historical empathy in these books, arguing that "the cause of the lack of sympathetic understanding is that the average citizen has not had an opportunity in school or out to learn what the science of cultural anthropology has to offer" (DuBois, 1942, p. 8). Although she never used the precise term historical empathy, DuBois clearly supported the curricular aims of historical empathy by encouraging "intergroup relations" through the conversations among diverse peoples that revealed multiple perspectives (Allport, 1955, p. 9).

Similar to Rugg's curriculum, DuBois' ICEM initiatives faced harsh criticism. According to Author (2007), DuBois' aversion to the 1924 anti-Asian immigration law and her interests in race relations caused organizations such as the local American Legion to call for her resignation from Woodbury High School. Although protected by New Jersey law, since she had a reputation for being an effective teacher, the backlash she faced was indicative of the challenges faced when teaching historical empathy as a curricular goal. Additionally, her radio show endured tough scrutiny from local school agencies and academic scholars. The General Education Board (GEB), which was a private organization that provided funds for educational programming, "shredded our efforts" (DuBois \& Okorodudu, 1984, p. 94). Years later, University of Minnesota professor Dr. Nicholas Montalto (1982) published a scathing review of the GEB's report of the ICEM initiatives and radio program, stating "it fell short of being an objective analysis of the Bureau's program and goals...running like a constant refrain through the report is the committee's skepticism with regard to the one fundamental assumption that...prejudices are dispelled and attitudes of understanding and appreciation of various cultures are built up through school experiences around the cultural contributions of the groups" (p. 242).

Despite these criticisms, along with the problematic conflations of historical empathy with sympathy in some ICEM programs and earlier progressive era reports, DuBois' consciousness of the concept of historical empathy as a curricular goal is seen in her works. She shifted ICEM aims from promoting "tolerance" to developing "sympathetic attitudes towards other nations and races," hence implementing historical empathy as a curricular goal in schools across the country (Author, 2007, 6p. 106; Davis, 1999, p. 170; DuBois, 1942).

\section{Discussion: Implications for today}

The origins of historical empathy lie in the works of the progressive era committee reports and educators who conceived of a history and social studies curriculum with the objective of fostering student understanding of sources to determine historical context, to recognize other perspectives, and to develop affective connections to content. Upon assessing some of the major documents of the time period, as well as leading social studies educators, evidence of historical empathy, albeit never explicitly stated, is present. The NEA Committee of Ten and Madison Conference's recommendations for source analyses demonstrated the beginning of the implied curricular goals of historical empathy. The AHA 
Committee of Seven suggested that the consideration of various viewpoints was an important skill for students to learn and master in order to demonstrate historical empathy. The works of the NEA CSS 1916 and 1918 Report further alludes to the existence of historical empathy as an implied social studies curricular goal through its suggestions for students to consider their own sympathies in order to understand the value of social institutions in a diverse democratic society. The founding of NCSS, Rugg's curriculum, and Rachel Davis DuBois' ICEM programs further demonstrate how historical empathy as an implicit curricular goal in social studies connects to civics and citizenship education through analysis of contemporary problems and learning about diverse peoples, cultures, and viewpoints.

Although considerable contemporary scholarship on instructional techniques that promote historical empathy has developed, currently it is not included as an explicit curricular goal in state and national social studies standards. However, the studies highlighted in this research, as well as recent policy initiatives, seem to support teachers who wish to pursue historical empathy in social studies instruction. For example, evidence of historical empathy as an inferred curricular goal in social studies can be seen in the Common Core Standards (CCS) for social studies (which are embedded in the ELA standards for grades 6-12). In the Grade 6-8 CCSS. ELA-LITERACY.RH.6-8.6 strand, students should be able to "Identify aspects of a text that reveal an author's point of view or purpose (e.g., loaded language, inclusion or avoidance of particular facts). The Grades 9-10 CCSS.ELA-LITERACY.RH.9-10.6 strand states that student should be able to "Compare the point of view of two or more authors for how they treat the same or similar topics, including which details they include and emphasize in their respective accounts." Students in Grade 11-12, according to the CCSS.ELA-LITERACY.RH.11-12.7 strand, states that students should be able to "Integrate and evaluate multiple sources of information presented in diverse formats and media (e.g., visually, quantitatively, as well as in words) in order to address a question or solve a problem." These excerpts from the CSS highlight the implicit existence of historical empathy concepts in social studies with its emphasis on student analysis of multiple sources to determine historical contexts and perspectives.

Similar to the documents from the progressive era, historical empathy is inferred in the CCS social studies strands, as students are encouraged to analyze several sources to determine historical context, consider perspectives, and make affective connections to content in order to solve a problem or take feasible agency in their community. Although some researchers believe the CCS "offers a more progressive, student-centered, constructivist approach to learning" (Ross, Matheson, \& Vinson, 2014, p. 34), implementation of standardized CCS exams by the states may undermine the standards' progressive inclinations by still focusing too much on tests to demonstrate student achievement and school accountability.

Consequently, we recommend further review of the CCS in order to evaluate their effectiveness in measuring student achievement, and whether historical empathy can be fostered in social studies.

Evidence of NCSS' continued move to support implied historical empathy curricular goals in social studies can be seen in its College, Career, and Civic Life Framework for Social Studies Standards (C3 Framework). Keeping with the tradition of 4earlier progressive era documents by the NEA, AHA, and early founding of NCSS, the "Introduction" of the C3 Framework states:

Now more than ever, students need the intellectual power to recognize societal problems; ask good questions and develop robust investigations into them; consider possible solutions and consequences; separate evidence-based claims from parochial 
opinions; and communicate and act upon what they learn. And most importantly, they must possess the capability and commitment to repeat that process as long as is necessary. Young people need strong tools for, and methods of, clear and disciplined thinking in order to traverse successfully the worlds of college, career, and civic life (p. 6).

The C3 Framework alludes to concepts of historical empathy. The document encourages students to engage in perspective recognition by asking questions, critically analyzing evidence-backed claims and opinions, and making affective connections to content.

Additionally, the term empathy is used twice in the C3 Framework. The "Perspectives" section that states:

History is interpretive. Even if they are eyewitnesses, people construct different accounts of the same event, which are shaped by their perspectives-their ideas, attitudes, and beliefs. Historical understanding requires recognizing this multiplicity of points of view in the past, which makes it important to seek out a range of sources on any historical question rather than simply use those that are easiest to find. It also requires recognizing that perspectives change over time, so that historical understanding requires developing a sense of empathy with people in the past whose perspectives might be very different from those of today (p. 47).

Moreover, empathy appears in the definition of personal values in the "Key Terms" section of the C3 Framework. This definition states:

Personal values: Ethical and moral commitments that guide individuals' actions and interpersonal relationships.

Example. Personal values include empathy, integrity, self-reliance, generosity, trustworthiness, and creativity (p. 102).

The C3 Framework is the most clearly articulated recommendation of historical empathy in the social studies curriculum to date. Its emphasis on examining the perspectives and context of perspectives, as well as its connection to ethics and moral education, highlights that great strides, albeit gradual, are pointing towards a more explicit fostering of historical empathy as a curricular goal in social studies education. These acknowledgements, as well as the implicit wording of the ESSA, provides evidence that although historical empathy is not a specifically written curricular goal, it exists as a major component of a challenging, authentic, and meaningful history and social studies education in the 21st century.

\section{Conclusion}

Documents from the Progressive Era and materials from social studies leaders of this time show that historical empathy has existed as an implied pedagogical and curricular goal in history and social studies education. Historical empathy was encouraged in the NEA and AHA reports on emphasizing history and social studies education in elementary and secondary schools, analysis of contemporary issues in Rugg's Problems of Democracy course, and DuBois' intercultural education movement programs. As the United States continues to face critical socio-economic and political issues reminiscent of the Progressive Era, recent initiatives such as the NCSS C3 Framework have made more specific references to historical 
empathy as a curricular goal through its focus on student examination of world views and contexts in order to understand con- temporary problems (Case, 1993).

Perhaps more than ever, historical empathy is needed as an explicit, not implied, social studies curricular goal. We believe that historical empathy is an important tool to foster understanding of historical contexts, multiple perspectives, and affective dimensions of history. Students who are able to engage in historical empathy will be better equipped to understand our past and face our present, diverse society.

\section{Uncited references}

Dunn (1916); James (1909); Loewen (2005); National Council for the Social Studies (2013); National Council for the Social Studies (2016); National Education Association (1894); National Education Association (1918); Whelan (1997).

\section{References}

American Historical Association (1898). The study of history in schools. Retrieved from 〈https://www.historians.org/about-aha-and-membership/aha-his tory-and-archives/archives/the-studyof-history-in-schools $\rangle$.

Author. (2001). Historical and international dimensions of history education: The work of the Committee of Ten. In A. Dickinson, P. Gordon, \& P. J. Lee (Eds.),

International review of history education: Raising standards in history education, Volume 3 (pp. 56-72). London: Woburn Press.

Author. (2003). Early vanguards of progressive education: The Committee of Ten, the Committee of Seven, and social studies education. Journal of Curriculum and Supervision, 19, 73-94.

Author. (2005). Digging trenches: Nationalism and the first national report on elementary history curriculum. Theory \& Research in Social Studies Education, 33, 266-291.

Author. (2007). A rebellious Jersey girl: Rachel Davis DuBois, intercultural education pioneer. In S. Totten, \& J. Pedersen (Eds.), Addressing social issues in the classroom and beyond: The pedagogical efforts of pioneers in the field. Charlotte: Information Age Publishing.

Author. (2009). Committee of eight. In E. F. Provenzo, E. F., Jr. (Ed.), Encyclopedia of the social and cultural foundations of education, Volume 1 (pp. 147-148).

Thousand Oaks, CA: Sage Publications.

Author. (2016). More than a feeling: A study on factors that promote historical empathy in middle and secondary social studies classes with the "Elizabeth Jennings Project" (Unpublished Dissertation). Atlanta, GA: Georgia State University.

Barton, K.C. (1996). Did the devil just run out of juice? Historical perspective taking among elementary students. New York, New York: Paper presented at the annual meeting of the American Educational Research Association. ERIC Document Reproduction Service. No. ED 401203. 
Barton, K. C., \& Levstik, L. S. (2004). Teaching history for the common good. Mahwah, New Jersey: Lawrence Erlbaum Associates, Inc. Blake, C. (1998). Historical empathy: A response to Foster and Yeager. International Journal of Social Education, 13(1), 25-31.

Boyle-Baise, L., \& Goodman, J. (2009). The influence of Harold O. Rugg: Conceptual and pedagogical considerations. The Social Studies, 100(1), 31-40. Bradley, A. (2007). A time to intervene: A historical overview of pedagogical responses to an unjust society. The Vermont Connection, 28(2), 70-79. Brooks, S. (2009). Historical empathy in the social studies classroom: A review of the literature. The Journal of Social Studies Research, 33(2), 213-234. Brooks, S. (2011). Historical empathy as perspective recognition and care in one secondary social studies classroom. Theory and Research in Social Studies

Education, 39(2), 166-202.

Case, R. (1993). Key elements of a global perspective. Social Education, 57(6), 318-325.

Colby, S. R. (2007). Students as historians: The historical narrative inquiry model's impact on historical thinking and historical empathy. https://digital.library.unt.edu/ark:/67531/metadc5192/.

Colby, S. R. (2008). Energizing the history classroom: Historical narrative inquiry and historical empathy. Social Studies Research and Practice, 3(3), 60-79.

Davis, O. L., Jr. (1999). Rachel Davis DuBois: Intercultural education pioneer. In M. S. Crocco, \& O. L. Davis, O. L., Jr. (Eds.), Bending the future to their will: Civic women, social education, and democracy. Lanham: Rowman \& Littlefield Publishers, Inc.

Davis, O. L., Jr. (2001). In pursuit of historical empathy. In O. L. Davis, E. A. Yeager, \& S. J. Foster (Eds.), Historical empathy and perspective taking in the social studies. Maryland: Roman and Littlefield.

Davis, O. L., Jr. (2012). Harold Rugg, the engineer, and the social studies Education Review, 15(3))1-13.

Dewey, J. (1938). Experience and education. In A. J. Milson, C. H. Bohan, P. L. Glanzer, \& J. W. Null (Eds.), American education thought, essays from 1640-1940. Charlotte, North Carolina: Information Age Publishing, Inc.

Dorn, C. (2008). Treason in the textbooks: Reinterpreting the Harold Rugg textbook controversy in the context of wartime schooling. Pedagogica Historica,44(4), 457-479.

DuBois, R. D. (1942). Get together Americans: Friendly approaches to racial and cultural conflicts through the neighborhood-home festival. New York: Harper \& Brothers.

DuBois, R. D., \& Okorodudu, C. (1984). All this and something more: Pioneering in intercultural education. Bryn Mawr, Pennsylvania: Dorrance \& Company, Inc. Duhlberg, N. (2002). Engaging in history: Empathy and perspective-talking in children's historical thinking, New Orleans, L.A.: Annual meeting of the

1American Educational Research Association (pp. 1-48). ERIC Document Reproduction service, No. ED 474135.

Dunn, A. W. (Ed.). (1916). The social studies in secondary education: Report of the committee on social studies of the commission on the reorganization of 
secondary education of the National Education Association. Washington, D.C: Department of the Interior Bureau of Education.

1Eliot, C. W. (1898). The function of education in democratic society. In A. J. Milson, C. H. Bohan, P. L. Glanzer, \& J. W. Null (Eds.), American education thought, essays from 1640-1940. Charlotte, North Carolina: Information Age Publishing, Inc.

1Endacott, J. L. (2014). Negotiating the process of historical empathy. Theory and Research in Social Studies Education, 42(1), 4-34.

Endacott, J. L., \& Brooks, S. (2013). An updated theoretical and practical model for promoting historical empathy. Social Studies Research and Practice, 8(1),

$41-58$.

1Evans, R. W. (2004). The social studies wars: What should we teach the children?. New York: Teachers College Press.

Fallace, T. (2012). The racial and cultural assumptions of the early social studies educators, 1901-1922. In C. Woyshner, \& C. H. Bohan (Eds.), Histories of social studies and race (pp. 1865-2000). New York: Palgrave Macmillan.

Fling, F. M. (1924). Review, The newspaper and the historian by Lucy Maynard Salmon. Political Science Quarterly, 39(4), 709-711.

Foster, S. J. (1999). Using historical empathy to excite students about the study of history: Can you empathize with Neville Chamberlain? The Social Studies, 290, 18-24.

James, J. A. (1909). Proposals of the Committee of Eight: A restatement of James Alton James, of Northwestern University, Chairman of the Committee. The Social Studies, 100(1), 4-5.

2Jensen, J. (2008). Developing historical empathy through debate: An action research study. Social Studies Research and Practice, 3(1), 55-67.

Johnson, H. (1922). Characteristic elements of social studies: History. The Historical Outlook: Continuing The History Teacher's Magazine (pp. 327-329). XIII, 9. Retrieved from 〈https://archive.org/stream/historicaloutlo00studgoog\#page/n398/mode/1up〉.

Jones, T. J. (1906). Social studies in the Hampton curriculum. Hampton, VA: Hampton Institute Press. Kohlmeier, J. (2005). The power of a woman's story: A three step approach to historical significance in high school world history. International Journal of Social Education, 20(1), 64-80.

Lal, S. (2004). 1930s Multiculturalism: Rachel DuBois and the Bureau for Intercultural Education. The Radical Teacher, 69, 18-22.

Lee, P., \& Ashby, R. (2001). Empathy, perspective taking, and rational understanding. In O. L. Davis, E. A. Yeager, \& S. J. Foster (Eds.), Historical empathy and

2perspective taking in the social studies. Maryland: Roman and Littlefield. 
Lee, P., \& Shemilt, D. (2011). The concept that dares not speak its name: Should empathy come out of the closet? Teaching History, 143, 39-49.

3Loewen, J. W. (2005). Sundown towns: A hidden dimension of American racism. New York: Touchstone Books. MacKenzie, J. C. (1894). Report of the Committee of Ten. The School Review, 2(3), 146-155.

Marcus, A. S., Metzger, S. A., Paxton, R. J., \& Stoddard, J. D. (2010). Teaching history with film: Strategies for secondary social studies. New York: Routledge.

3Metzger, S. A. (2012). The borders of historical empathy: Students encounter the Holocaust through film. Journal of Social Studies Research, 34(4), 387-410. Montalto, N. (1982). A History of the intercultural education movement. New York: Garland Publishing, Inc.

Mraz, M. (2004). Harold O. Rugg and the foundations of social studies. International Journal of Social Studies Education, 19(1), 1-7.

National Council for the Social Studies. (2013). The college, career, and civic life (C3) Framework for social studies state standards: Guidance for enhancing the rigor of K-12 civics, economics, geography, and history. Silver Spring, MD: NCSS Retrieved from

〈http://www.socialstudies.org/sites/default/files/c3/C3-3Framework-for-Social-Studies.pdf〉.

National Council for the Social Studies. (2016). A vision of powerful teaching and learning in the social studies: A position statement of the National Council for the Social Studies. Social Education, 80(3), 180182.

3National Education Association. (1894). Report of the Committee of Ten on secondary school studies. In A. J. Milson, C. H. Bohan, P. L. Glanzer, \& J. W. Null (Eds.), American education thought, essays from (pp. 1640-1940). Charlotte, North Carolina: Information Age Publishing, Inc.

National Education Association. (1918). Cardinal principles of secondary education. A report of the commission on the reorganization of secondary education appointed by the National Education Association. Washington, D.C: Department of the Interior Bureau of Education.

Q9 National Education Association Madison Conference. (1892). Report of the committee on secondary school studies appointed at the meeting of the National Education Association July 9, 1892. Washington, D.C: Government Printing Office. Cornell University Library Retrieved from〈https://archive.org/stream/cu31924030593580\#page/n3/mode/2up〉.

Nelson, J. L. (2001). Defining social studies. In W. B. Stanley (Ed.), Critical issues in social studies research for the 21st century. Greenwich: Information Age Publishing.

Nelson, M. R. (1975). Building a science of society: The social studies and Harold Rugg (Unpublished Dissertation). Stanford, CA.: Stanford University.

Noddings, N. (2002). Education moral people: A caring alternative to character education. New York: Teacher's College Press.

Novick, P. (1988). That noble dream: The 'objectivity question' and the American historical profession. Cambridge University Press. Pitkin, V. E. (1948). An appraisal of the intercultural education movement. The High School Journal, 31(3), 112-118. 
Reese, W. J. (2001). Origins of progressive education. History of Education Quarterly, 41(1), 1-24. Reese, W. J. (2007). History, education, and the schools New York: Palgrave MacMillan.

Riis, J. A. (1901). How the other half lives: Studies among the tenements of New York. New York: Dover Publications, Inc.

Rugg, H. (1929). An introduction to American civilization: A study of economic life in the United States. New York: Ginn \& Company. Rugg, H., \& Mendenhall, J. E. (1929). Teacher's guide for an introduction to American civilization. New York: Ginn \& Company.

Savage, B. D. (1999). Broadcasting freedom: Radio, war, and the politics of race (pp. 1938-1948) Chapel Hill: University of North Carolina Press1938-1948. Saxe, D. W. (1991). Social studies in schools: A history of the early years. Albany, NY: State University of New York Press.

The Historical Outlook (1921). A National Council for the Social Studies. The Historical Outlook: Continuing the History Teacher's Magazine (p. 144). XII, 4. Retrieved from 〈https://archive.org/stream/historicaloutlo00studgoog\#page/n151/mode/1up〉.

Thornton, S. J. (1996). NCSS: The early years. In O. L. Davis (Ed.), NCSS in Retrospect. Washington, D.C: National Council for the Social Studies. Vinovskis, M. A. (1999). History and educational policymaking. New Haven, CT: Yale University Press.

Vinson, K. D., \& Ross, E. W. (2001). In search of the social studies curriculum: Standardization, diversity, and a conflict of appearances. In W. B. Stanley (Ed.), Critical issues in social studies research for the 21st century. Greenwich: Information Age Publishing.

Whelan, M. (1997). A particular lucid lens: The Committee of Ten and the social studies committee in historical context. Journal of Curriculum and Supervision, 12(3), 256-268.

Yilmaz, K. (2007). Historical empathy and its implications for classroom practices in schools. The History Teacher, 40(3), 331-337. 